\title{
Stimulation of Phenotypically Normal Shoot Regeneration of Tomato (Lycopersicon esculentum Mill.) by Commercial Filter Paper Extract
}

\author{
Kazuo Ichimura and Masayuki Oda * \\ National Research Institute of Vegetables, Ornamental Plants and Tea, Ano, Mie 514-2392
}

\begin{abstract}
Summary
Effects of extracts from filter paper on the shoot regeneration of tomato (Lycopersicon esculentum Mill.) were examined. Cotyledon segments of tomato were cultured on supporting material made of polyester supplemented with Murashige and Skoog liquid medium, containing $0.1 \mathrm{mg} \cdot \operatorname{liter}^{-1}$ indole-acetic acid, $1.0 \mathrm{mg} \cdot \operatorname{liter}^{-1}$ zeatin and $3 \%$ sucrose. Soluble components were extracted from filter paper with hot water and added to the medium. Phenotypically normal shoot regeneration was stimulated by the extracts of filter paper; the highest percentage of shoot regeneration was obtained by an extract equivalent to $1 \mathrm{~g}$ filter paper per ml. When filter paper extracts were fractionated on Sephadex G-25 gel column, the shoot regeneration stimulating activity was found in a low molecular weight fraction. These results suggest that filter paper contains thermostable substances low molecular weight which induce shoot regeneration.
\end{abstract}

Key Words: biological activity, filter paper, polyester support, shoot regeneration, tomato.

\section{Introduction}

Filter paper is a material used for removing solids from solutions, support for paper chromatography and a moist medium for germinating seeds. Furthermore, filter paper is often applied for paper-bridge-(Bhat et al., 1992) and paper-wick-systems (Baker and Phillips, 1962) in plant tissue culture.

Ichimura et al. (1995) reported that gelling agents or supporting materials, derived from plant polysaccharides, were much more effective for shoot regeneration from cotyledonary segments of tomato than any other support materials made from polyester or ceramic. Furthermore, Ichimura and Oda (1995) and Ichimura et al. (1995) found that wood pulp and agar extracts stimulated shoot regeneration of tomato when they were added to a liquid medium utilizing a polyester support. These results suggest that some water-soluble substances derived from plant polysaccharides promote shoot regeneration of tomato. Filter paper is made primarily of cellulose from cotton; its extract may have some stimulating agents for shoot regeneration.

The purpose of this study is to investigate effects of filter paper extracts on adventitious shoot regeneration from tomato tissues.

\section{Materials and Methods}

Nine hundred $g$ of filter paper (No. 2, Toyo Roshi Kaisha, Ltd.) was minced (ca. $2 \mathrm{~cm}$ diam.) and soaked

\footnotetext{
Received; June 4, 1997. Accepted; July 30, 1997.

* Present address : College of Agriculture, Osaka Prefecture University, Gakuen-cho, Sakai, Osaka 599-8231
}

in 18 liter of distilled water at a temperature of $80{ }^{\circ} \mathrm{C}$. The mixture was kept at $80{ }^{\circ} \mathrm{C}$ in an oven for $1 \mathrm{hr}$. Upon cooling to room temperature, the mixture was filtered through the same type of filter paper and concentrated to $140 \mathrm{ml}$ in vacuo with a rotary evaporator below $50{ }^{\circ} \mathrm{C}$. The concentrated extract was frozen at -30 ${ }^{\circ} \mathrm{C}$ until it was used.

Supporting material made of polyester (Cloud; Toyobo Co., Ltd.) was placed into culture vessels $(6.2$ $\times 6.2 \times 9.8 \mathrm{~cm})$. The weight and size of polyester support were $1.5 \mathrm{~g}$ and $5.5 \times 5.0 \times 1.5 \mathrm{~cm}$, respectively. MS liquid medium (Murashige and Skoog, 1962) supplemented with $3 \%$ sucrose, $0.1 \mathrm{mg} \cdot$ liter $^{-1}$ indole-acetic acid and $1.0 \mathrm{mg} \cdot$ liter $^{-1}$ zeatin and a known amount of filter paper extracts $(\mathrm{pH} 5.8)$, was poured into the vessel and autoclaved at $121{ }^{\circ} \mathrm{C}$ for $10 \mathrm{~min}$. The total volume of medium was $55 \mathrm{ml}$. Four excised cotyledonary segments (ca. $5 \times 3 \mathrm{~mm}$ ) of tomato (Lycopersicon esculentum Mill. cv. Zuiken) prepared according to Ichimura and Oda (1995) were placed onto the support in each of two vessels per treatment. The segments were cultured as described by Ichimura et al. (1995).

To examine molecular weights of active substances, an extract obtained from filter paper $(7 \mathrm{~kg})$ was concentrated to $43 \mathrm{ml}$ as above. The concentrate was loaded onto a Sephadex G-25 (fine) column $(4 \times 90 \mathrm{~cm})$; which was equilibrated and then eluted with distilled water at room temperature. The flow rate was $100 \mathrm{ml} \cdot \mathrm{hr}^{-1} ; 12$ $\mathrm{ml}$ in each fraction was collected. The column was calibrated with blue dextran (mol. wt. 2,000,000), stachyose tetrahydrate (mol. wt. 738 ), sucrose (mol. wt. 342), and glucose (mol. wt. 180). Aliquots of each fraction were assayed for sugar by the method of Dubois et 
al. (1956).

\section{Results and Discussion}

In this study, we used polyester support instead of agar, because polyester support is guaranteed not to release its contents into the medium nor to absorb components from it (Toyobo, 1988), so that, only the direct effects of medium on explants can be observed. Irrespective of presence of filter paper extracts, margins of the explants became callused after 2 weeks of culture, and adventitious buds regenerated from the calluse after 3 weeks. There was little difference in the morphology of adventitious buds between tissues exposed to filter paper extracts and those of the control up to seven weeks of culture. Thereafter, differences in the subsequent growth between the treatment and control became apparent. Most adventitious shoots in the control tissues became abnormally thickened and frequently vitrified and phenotypically normal shoots rarely regenerated. The addition of the filter paper extracts to the polyester medium stimulated the adventitious buds to grow into phenotypically normal shoots. This result reveals that the filter paper extracts contain substances that stimulate phenotypically normal shoot regeneration. The optimum concentration of the extracts for shoot growth was calculated to be equivalent to $1 \mathrm{~g}$ per ml (Table 1). The weight of the extracts recovered from $1,000 \mathrm{~g}$ of filter paper being about $280 \mathrm{mg}$, the concentration of the extract equivalent to $0.1 \mathrm{~g}$ of filter paper per liter which was the minimum concentration to stimulate shoot regeneration is estimated to be $0.3 \mathrm{mg}$ - liter ${ }^{-1}$. Hence, some stimulating substances contained in the commercial filter paper is effective at a concentration less than one ppm level.

The filter paper extract was fractionated on a Sephadex G-25 column, and the sugar concentration in each fraction of the eluate was assayed because filter paper mainly consisted of the plant polysaccharide, cellulose. Whereas the main component of the extract was a polysaccharide-like substance, a low molecular weight fraction was also positive to phenol-sulfuric acid reaction (Fig. 1). We divided the eluate into 4 fractions, and examined the effects of fractions on shoot regeneration. Percentages of explants with normal leaves, number and length of normal leaves exposed to fraction III whose molecular weight was equivalent to several hundreds were greater than those exposed to any other fractions (Table 2). These results indicate that some stimulating substances are a low molecular weight compound.

To our knowledge, we are first to report that commercial filter paper has biological activity. This finding should be of interest because filter paper is routinely used in biological and chemical experiments, especially in tissue culture as a paper-bridge-system which facili-

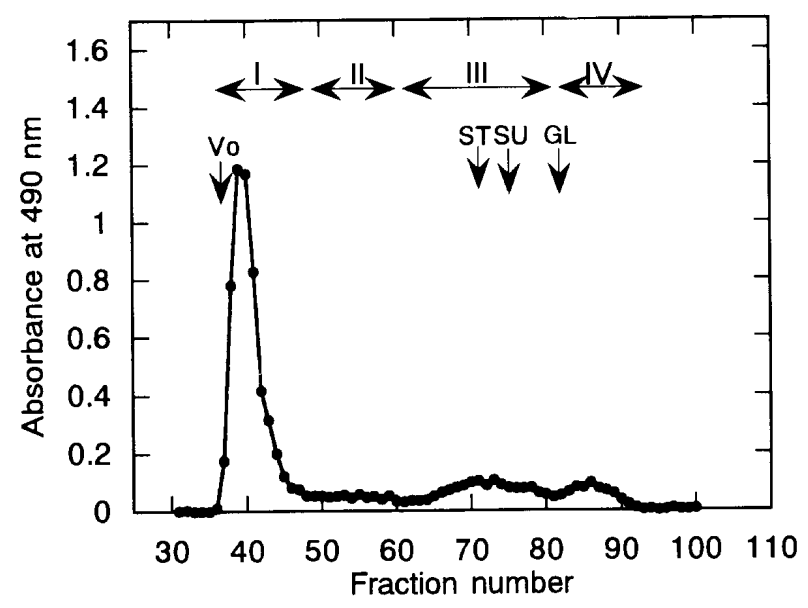

Fig. 1. Sephadex G-25 elution profile of filter paper extract. Twelve $\mathrm{ml}$ in each fraction was collected and aliquot $(10 \mu$ 1) of each column fraction was assayed for sugar content. Curve represents sugar content expressed as absorbance at $490 \mathrm{~nm}$. Void volume (Vo) was determined by blue dextran. Elute portions of stachyose tetrahydrate (ST), sucrose (SU) and glucose (GL) were indicated by arrows. Eluate was divided into 4 fractions, I, II III and IV, and their effects on the shoot regeneration was shown in Table 2.

Table 1. Effect of filter paper extract on shoot regeneration of tomato. The data were taken after 104 days of culture. Values represent mean of 8 replications \pm standard errors.

\begin{tabular}{|c|c|c|c|c|c|}
\hline $\begin{array}{l}\text { Concentration } \\
\text { (g equivalent } \cdot \mathrm{ml}^{-1} \text { ) }\end{array}$ & $\begin{array}{l}\text { Percentage } \\
\text { of explant } \\
\text { with normal } \\
\text { leaves } \\
\quad(\%)\end{array}$ & $\begin{array}{l}\text { Number of } \\
\text { shoot per } \\
\text { explant }\end{array}$ & $\begin{array}{l}\text { Number of } \\
\text { shoot with } \\
\text { normal leaves } \\
\text { per explant }\end{array}$ & $\begin{array}{l}\text { Shoot } \\
\text { length }\end{array}$ & $\begin{array}{l}\text { shoot length } \\
\text { with normal } \\
\text { leaves" } \\
\text { (mm) }\end{array}$ \\
\hline 0 & 12.5 & $0.6 \pm 0.2$ & $0.1 \pm 0.1$ & $11.0 \pm 3.6$ & $4.5 \pm 4.2$ \\
\hline 0.001 & 50 & $1.1 \pm 0.5$ & $0.6 \pm 0.3$ & $18.6 \pm 7.9$ & $16.0 \pm 8.5$ \\
\hline 0.01 & 50 & $1.6 \pm 0.4$ & $0.9 \pm 0.4$ & $29.4 \pm 10.0$ & $24.6 \pm 11.2$ \\
\hline 0.1 & 75 & $1.0 \pm 0.2$ & $0.8 \pm 0.2$ & $23.6 \pm 8.6$ & $22.0 \pm 9.0$ \\
\hline 1 & 100 & $1.4 \pm 0.3$ & $1.3 \pm 0.3$ & $44.9 \pm 12.2$ & $44.5 \pm 12.4$ \\
\hline 2 & 87.5 & $0.8 \pm 0.3$ & $0.8 \pm 0.3$ & $27.4 \pm 17.2$ & $27.4 \pm 17.2$ \\
\hline
\end{tabular}

Percentage of explant produced phenotypically normal leaves.

Number of shoots longer than $10 \mathrm{~mm}$.

Number of shoots longer than $10 \mathrm{~mm}$ with phenotypically normal leaves.

Length of longest shoot each explant produced.

Length of longest shoot with phenotypically normal leaves each explant produced. 
Table 2. Effect of fractions of filter paper extract separated by a Sephadex G-25 column on phenotypically normal shoot regeneration of tomato. Values represent mean of 8 replications. The data were taken after 105 days of culture.

\begin{tabular}{ccccc}
\hline \hline Fraction & Concentration & $\begin{array}{l}\text { Percentage } \\
\text { of explant } \\
\text { with normal } \\
\text { leaves } \\
\text { ( }\end{array}$ & $\begin{array}{l}\text { Number of } \\
\text { shoot with } \\
\text { normal leaves } \\
\text { per explant }\end{array}$ & $\begin{array}{l}\text { Shoot length } \\
\text { with normal } \\
\text { leaves }\end{array}$ \\
\hline Control & 0 & 0 & 0 & (mm) \\
I & 0.22 & 0 & 0 & 0 \\
& 2.2 & 0 & 0 & 0 \\
II & 0.22 & 0 & 0 & 0 \\
& 2.2 & 0 & 0 & 0 \\
III & 0.22 & 50.0 & 0.6 & 0 \\
& 2.2 & 37.5 & 0.6 & 24.8 \\
IV & 0.22 & 25.0 & 0.1 & 12.8 \\
& 2.2 & 12.5 & 0.1 & 1.5 \\
\hline
\end{tabular}

Percentage of explant produced phenotypically normal leaves.

Number of shoots longer than $10 \mathrm{~mm}$ with phenotypically normal leaves.

Length of longest shoot with phenotypically normal leaves each explant produced.

tated rooting (Bhat et al., 1992), and the paper-wicksystem for apical meristem culture (Baker and Phillips, 1962) and floral differentiation of Torenia (Kobayashi et al., 1993). These positive effects on cultured tissues may also be related to the shoot regeneration-stimulating substances in filter paper.

The regeneration-stimulating activity was partitioned by hot water extracts, so the stimulant seems to be a heat-stable, hydrophilic compound. Agar or supporting materials made of wood pulp or cotton fiber or their extracts were found to stimulate shoot regeneration of tomato (Ichimura and Oda, 1995; Ichimura et al., 1995). Therefore, the active substance in filter paper may be related to plant polysaccharides just as Bois (1992) suspected because, in that study, cotton hydrolysate induced differentiation and organogenesis from callus of strawberry.

\section{Acknowledgements}

We thank Toyobo Co. for kindly providing us polyester support, and Mrs. T. Yamakawa for her technical assistance. This work was supported in part by a Grantin-Aid (Glyco-technology Program) from the Ministry of Agriculture, Forestry and Fisheries.

\section{Literature Cited}

Baker, R. and D. J. Phillips. 1962. Obtaining pathogen-free stock by shoot tip culture. Phytopathology 52 : 1242-1244.

Bhat, S. R., P. Chitralekha and K. P. S. Chandel. 1992. Regeneration of plants from long-term root culture of lime, Citrus aurantifolia (Christm.) Swing. Plant Cell Tiss. Org. Cult. 29 : 19-25.

Bois, F. 1992. The influence of some natural cell-wall derived precursors on organogenesis and differentiation of wild strawberry (Fragaria vesca L.) callus culture. Plant Cell Tiss. Org. Cult. 28 : 91-96.

Dubois, M., K. A. Gilles, J. K. Hamilton, P. A. Roberts and F. Smith. 1956. Colorimetric method for determination of sugars and related substances. Anal. Chem. 28 : 350-356.

Ichimura, K. and M. Oda. 1995. Stimulation of shoot regeneration from cotyledon segments of tomato (Lycopersicon esculentum Mill.) by agar and its extract. J. Japan. Soc. Hort. Sci. 64 : 135-141.

Ichimura, K., T. Uchiumi, K. Tsuji, M. Oda and M. Nagaoka. 1995. Shoot regeneration of tomato (Lycopersicon esculentum Mill.) in tissue culture using several kinds of supporting materials. Plant Sci. 108 : 93-100.

Kobayashi, S., W. Amaki and H. Higuchi. 1993. Effects of sugar on in vitro flowering of internodal segments in Torenia fournieri Lind. Plant Tissue Cult. Lett. 10 : 298-300. (In Japanese).

Murashige, T. and F. Skoog. 1962. A revised medium for rapid growth and bio-assays with tobacco tissue culture. Physiol. Plant. 15 : 473-497.

Toyobo. 1988. Polyester support for plant tissue culture. Toyobo Co. Osaka, p. 10. (In Japanese).

市販ろ紙の抽出液によるトマト子葉からのシュート再生の促進

$$
\text { 市村一雄・小田雅行* }
$$

野菜・茶業試験場 514-2392 三重県安芸郡安濃町草生

\begin{abstract}
摘 要
市販ろ紙の熱水抽出液がトマト子葉片からのシュート再生 に及ぼす影響について調べた。トマト子葉片をポリエステル 製の支持体上で培養したところ，ろ紙抽出液によりトマト子 葉片からのシュート再生は著しく促進された。抽出液を

分子画分にみられたが，活性は低分子画分に存在した，以上 の結果より，市販のろ紙にはトマトのシュート再生を促進す る熱安定性の低分子の物質が含まれていることが明らかとな った.
\end{abstract} Sephadex G-25 カラムで分画したところ，主要な成分は高
$*^{*}$ 現在 $:$ 大阪府立大学農学部 